\title{
Distributed Energy Resources and Supportive Methodologies for their Optimal Planning under Modern Distribution Network: a Review
}

\author{
Umesh Agarwal $^{1} \cdot$ Naveen Jain ${ }^{1}$
}

Received: 1 February 2018 / Accepted: 8 January 2019 / Published online: 18 January 2019

(C) Springer Nature Singapore Pte Ltd. 2019

\begin{abstract}
Rapid growth in electrical load demand with lack in generation of electrical power and transmission line congestion has set the trend for smart electrical system. In smart electrical system, need arises to deploy more non-conventional energy sources, which include Renewable Energy Sources (RES) as well as non-RES. Though, the RES are getting more encouragement due to several advantages over non-RES. In recent past, there is significant increase in the penetration of small units of local generation in existing distribution system. These small units (RES and non-RES), usually known as Distributed Generation (DG), may offer several technical, economic and environmental benefits like reduction in power loss, improvement in power quality, reliability, system security, reduction in capital cost investment at large level, reduction in emission of green-house gases and many more. However, these advantages are difficult to achieve due to some technical and non-technical barriers. To extract maximum potential benefits from the DG, the optimal planning of such sources in distribution network has always been a topic of great interest. Though, fresh researchers face many problems in carrying out research in this area due to lack of knowledge about suitable research software, standard test networks, types of renewable/non-renewable sources, appropriate literature, etc. This paper uses a systematic approach to discuss the DG and its technologies with advantages, disadvantages and effects on end users as well as on the utility. A comparative study of all optimization techniques for planning of DG in existing power system considering optimal size and location is also included. This paper also involves the details about some standard test systems along with details of useful software's (licensed \& open source) for DG planning. The present study can add worthful information and serve as a base for the fellow working in this area.
\end{abstract}

Keywords Distributed generation $\cdot$ Distributed generation planning $\cdot$ Modern distribution system $\cdot$ Optimization approach $\cdot$ Power system $\cdot$ Renewable energy sources

\section{Introduction}

According to an estimation of United States (US) energy information administration, it is expected that electricity generation may increase by a very high percentage during the period 2016 to 2040 . The growth may be significantly higher than global energy consumption. The RES will contribute greatly to the power generation mix with non-RES and other conventional sources to achieve the target as shown in Fig. 1 [1].

Umesh Agarwal

umeshbkb.agarwal@gmail.com

1 Department of Electrical Engineering, College of Technology and Engineering, Udaipur, Rajasthan, India
In the last few years, penetration of the RES has been increased by tremendous rate. There are several factors such as government motivation in term of several incentives, environmental consciousness of society and advancement in technologies. Further, the key factors are changing the pace of power generation as the system is moving towards local generation near to their locality such as generation at home by solar, bio-mass and wind energy sources.

The local generation is affecting power flow direction as compared to the network with traditional centralized power generation sources, which has unidirectional power flow. In modern distribution systems, real power flow with the DG can be bi-directional. Since, the DG (renewable/non-renewable type) includes a broad range starting from $1 \mathrm{~kW}$ to $100 \mathrm{MW}$ $[2,3]$, which can reverse the direction of real power at light 
Fig. 1 Evolution of global electricity generation by various sources of energy (Trillion $\mathrm{kWh}$ ) [1]

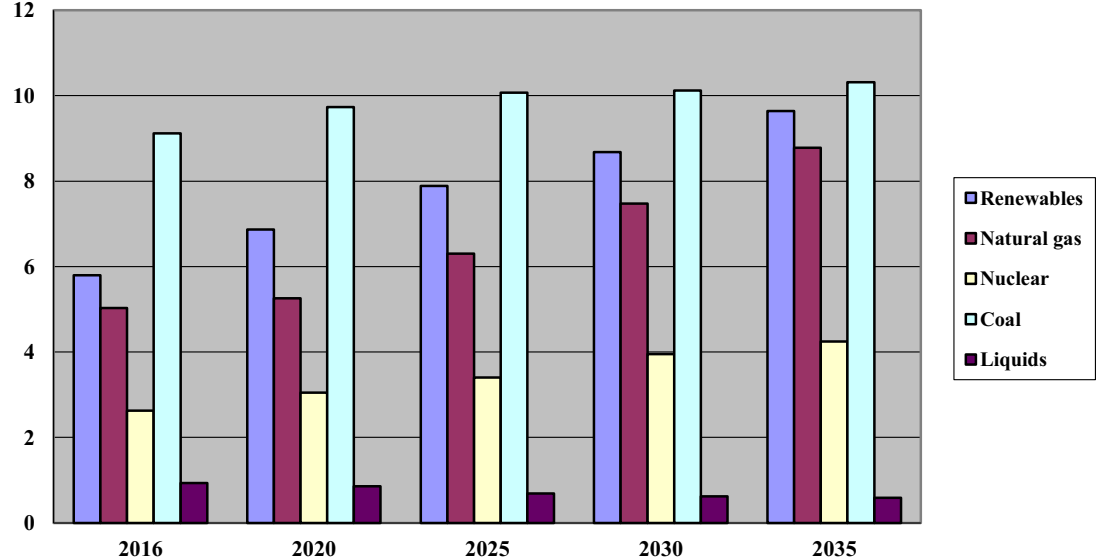

load or no load condition. In [4], Khatod suggested a broad classification as following:

(a) Micro DG $(1 \mathrm{~W}<5 \mathrm{~kW})$,

(b) Small DG $(5 \mathrm{~kW}<5 \mathrm{MW})$,

(c) Medium DG ( $5 \mathrm{MW}<50 \mathrm{MW})$

(d) Large DG (50 MW <300 MW).

The above classification was also discussed in [5-8]. The DG units provide technical, economical and environmental advantages subject to planning strategy and technologies used for the DG. The technical advantage is an important concern as it reflects system health in terms of power loss, voltage profile, reliability and power quality. The DG can improve system performance. Further, it can also mitigate harmonics, voltage sag and swell significantly along with reduced investment in transmission and distribution [9-13].

There are certain challenges with DG technologies such as stability issues of power system due to intermittent source of energy, protection problem due to bi-directional flow of real power, frequency stability, islanding difficulties [1-105]. Therefore, some factors need to be considered for planning of sources in distribution networks [5, 6], [8], [14, 15].

- Power injection pattern from the DG is very important as it depends upon type of generation source, whether renewable or non-renewable. Hence, researchers must take care while choosing any renewable/non-renewable source for their study $[16,17]$.

- The optimal planning has its importance in improving overall performance of the system for getting the best possible potential from the DG.

- There is a great issue with the DG as it can cause bidirectional flow of real power. Therefore, suitable protection schemes need to be considered with load growth.

This work is prepared considering the importance and the necessity of the DG in existing power system. It includes a vast overview of the work carried out in the DG planning. Further, there are some important distribution systems, which required in planning of distribution system with the DG, are discussed with schematic figures. Moreover, a detailed section is given to discuss various open source and licensed software, which can be great help to the researchers.

This paper is organized as: Section II represents the details of the DG such as DG techniques, potential benefits and impacts of the DG. Section III introduces a brief overview of techniques used for planning of the DG in power system to extract maximum potential advantages. Section IV, chronologically, represents the involvement of the reviewed work. Section V includes the key issues for the DG integration in existing power system. In Section VI includes important test systems that are considered in several well established literatures. Some key supportive tools both open source and licensed (planning of the DG) are discussed in Section VII. Finally, Section VIII covers discussion and conclusion.

\section{Distributed Generation}

In [8], the DG is represented as a source of electrical energy that is connected to the radial structure of distribution system near the customer end.

According to International Council on Large Electric System, any generation units, connected to distribution network and having capacity from $50 \mathrm{MW}$ to $100 \mathrm{MW}$, without facility of central planning and dispatchability is termed as DG [18].

Institute of Electrical and Electronics Engineer (IEEE) considers the DG as facility, comparatively smaller than central power plant and can be allocate at anywhere in power system [19].

The Electric Power Research Institute (EPRI) defines the DG as generation unit having maximum capacity up to 
$50 \mathrm{MW}$ along with energy storage devices connected at consumers end or at distribution or sub-transmission substations [20]. Considering all the above views about the DGs, it can be concluded that the DG is a small source of electric power, connected near the load point or in the distribution network. The size of the DG is sufficiently smaller than the central power generation source.

A significant development in technology is making loads more sensitive. In addition, present polluted environment is attracting people towards the use of renewable energy. These are some factors providing momentum to go for renewable energy based DG. The DG has become a matter of interest for researchers, academicians and environmentalists due to its numerous advantages over conventional generating sources $[5],[8,9],[14,15]$.

\section{Key DG Technologies}

Renewable energy sources as DG are beneficial in contrast of reduction in green-house gases, but uncertainties in power supply is also an issue. Some of the Renewable technologies require large space but most can be concise at small place like bio-gas plant for installation and initial cost is high, however, still less than centralized power generating source. Currently, to a certain extent, some of the DG technologies are still in research and under development phase. The major DG technologies with their range of electric power generation, primary source of energy, cost of installation is shown in Tables 1 and 2 $[4,7,14,21]$.

\section{After-Effects of DG}

The impacts of the DG can be generally classified into three categories as technical, financial and environmental impacts.

Technical issues: Insertion of the DG in existing distribution network is beneficial in many technical aspects. The DG is installed near load centre, therefore, reduces power loss and at the same time improves voltage profile by keeping the voltage in limits. The DG improves reliability, system security and energy efficiency of the supply. All these benefits appears only if the DG is planned optimal, otherwise, the DG may produce several technical problems as presented in [2, 5], [14, 15], [7-9], [22-27].

Financial issues: Installation of the DG is beneficial for the utility as well as the customer. Since, the DG reduces the capital cost by delaying the need for investment in new transmission and distribution infrastructure. It also reduces depreciation costs of the fixed assets in the network, loss in the system

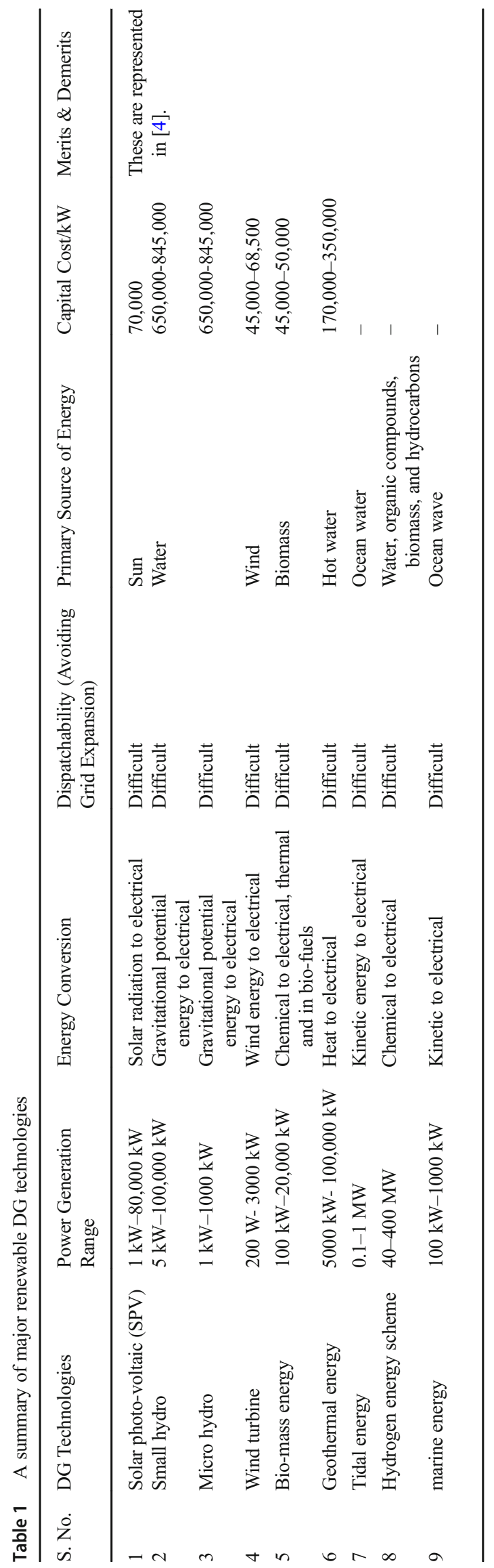




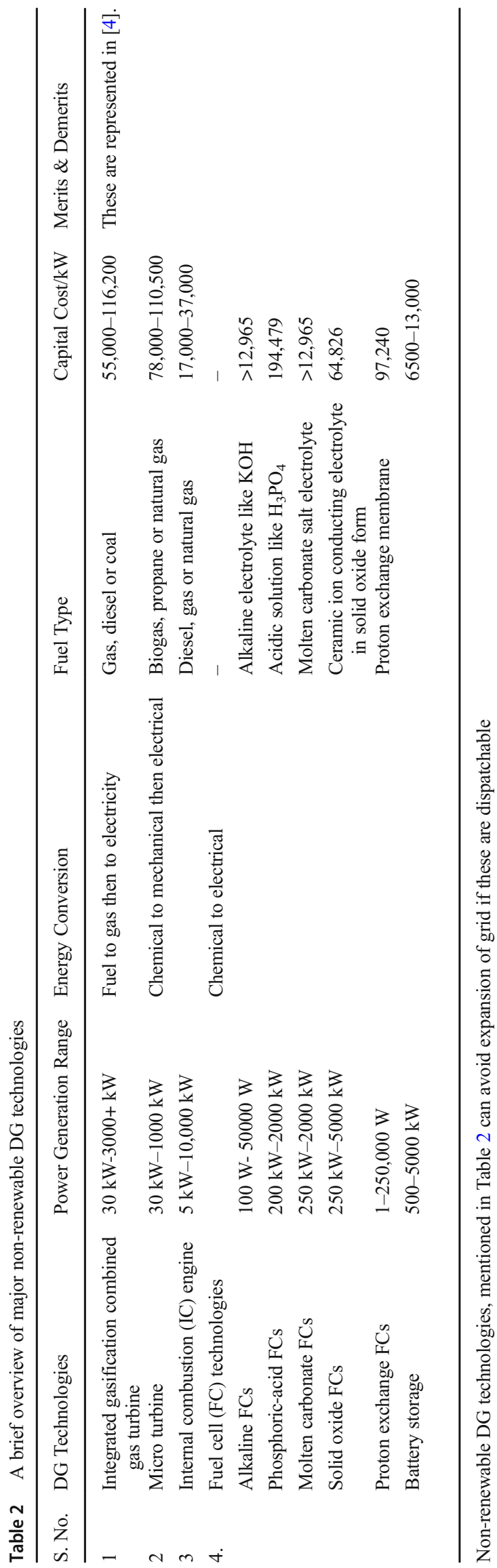

network, operation \& maintenance costs. The DG reduces electricity tariffs by creating favourable market environment for new agents $[3,5,14,28]$.

Environmental issues: Major DG technologies are associated with renewable sources; therefore, it is possible to generate green energy. As per the published literature, fuel burning is the main cause of around $80 \%$ pollution all over the world [23-25]. Many researchers have proved that the DG technologies, mainly renewable energy based, are capable of reducing the emission of carbon, technology and capable to cut the emission of carbon by approximately $40 \%$ [7]. As per the above mentioned definitions, it is clear that the DG can be installed near the load centres. Hence, there is no need of large space and it reduces deforestation. Though, there are some adverse impacts of renewable technologies on environment. Wind turbines are particularly not favorable to the bird species. Moreover, wind turbine required to be dug deep into the earth, which off-course has negative effect on underground habitats. In addition, it creates noise pollution. Similarly, ocean wave energy can be harmful to local water species during energy production.

\section{Popular Techniques for Optimal Sizing and Sitting of the DG}

The DG planning depends upon the requirement of the system such as: (a) Technical Issues (b) Economic Issues (c) Environmental Issues. In technical issues, key issues of the DG planning are voltage profile improvement, energy loss minimization, harmonics reduction, mitigating the issues of intermittent nature of the DG and maximization of reliability. There are several economic issues related to distribution system where the DG can help in mitigating such issues. Therefore, economic issues can be as key objective of the planning, whereas sometimes it can be merely a constraint. In several developed country, environmental issues are so important that the DG planning primarily considers it. Thus, the RES are mainly considered in such countries even they are costlier option.

The DG can be planned to address single or multiple issues, which may be combination of above said issues. This makes planning as single objective or multi-objective planning with or without constraint. In continuation, selection of the optimizing tool is based on nature of the planning and system constraints.

To maximize the requirement of the system, it is necessary to place the DG with proper sizing and siting 
considering the key constraints in distribution system. Such planning can result as desirable output. Hence, there are a lot of techniques available in the literature as per the objectives of the planning [125-135].

The following techniques have been adopted by the researchers to serve the objectives of sizing and siting of the DG in appropriate manner. The major acting techniques can be categorized as follows [12, 29].

- Analytical Techniques

- Classical Optimization Techniques

- Artificial Intelligent (Meta-heuristic) Techniques

- Miscellaneous Techniques

- Other Techniques for Future Use

\section{Analytical Techniques}

In Analytical techniques, mathematical replica is used to represent the system and numerical solution of the system, which can be computed reliably. Beauty of this technique is less computation time, high efficiency and simplicity of system with less state variables. Accomplishment of the technique has been reported in $[2,3],[10-12],[15,16]$, [29-32]. However, Analytical techniques may have some restrictions for bulky and difficult systems. These optimization techniques broadly include many key techniques and some of them are shown in Fig. 2.

\section{Classical Optimization Technique}

These optimization techniques are utilized to expand the advantage of the system according to the created formulation as per the necessity under given circumstances with system limitations. In this way, it needs to apply an appropriate optimization technique to get the required aimed function. These optimization techniques mainly cover important methods as shown in Fig. 3.

\section{Artificial Intelligent Techniques}

The beauty of Artificial Intelligence (AI) technique lies in getting well-organized, precise and best possible solutions wisely. The supposition extracted from the AI technique is the most up to date and adorable meta-heuristic explore technique. There are some other family optimization algorithms that have been adopted in meta-heuristic as shown in Fig. 4 [4-6], [13, 22], [25-28], [2, 33-45].

\section{Miscellaneous Techniques}

There are many more verities of methods observed in the work of literature, which are kept under miscellaneous techniques as shown in Fig. 5.

\section{Future Promising Optimizing Techniques}

There might be several new optimization techniques, with capabilities to have room for the multifaceted questions of the DG planning with multi-objective function, which can be classified as shown in Fig. 6 .

\section{Significant Contribution in the Reviewed Planning of the DG}

Table 3 describes the main contribution of the published DG works reviewed in this paper in a chronological order.

\section{Challenges with Distributed Generation}

Integration of the DG in distribution network has lots of benefits including technical, economic and environmental. Still, integration of the DG unit with existing power system is facing some challenges $[4,8,28,36]$, [90-92]. These are divided into three categories as:

- Technical issues

- Economical issues

- Operational \& connection issues

These all issues are discussed in detail under this section.

\section{Technical Issues}

The prime objective of the DG integration with existing distribution network is to overcome technical troubles

Fig. 2 Analytical techniques

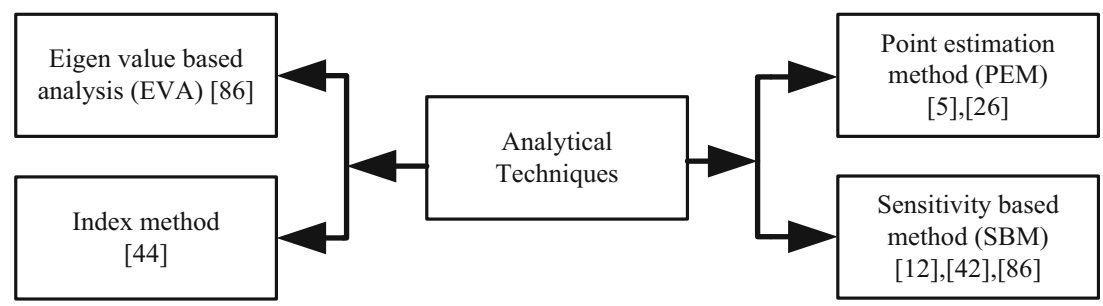


Fig. 3 Classical optimization techniques

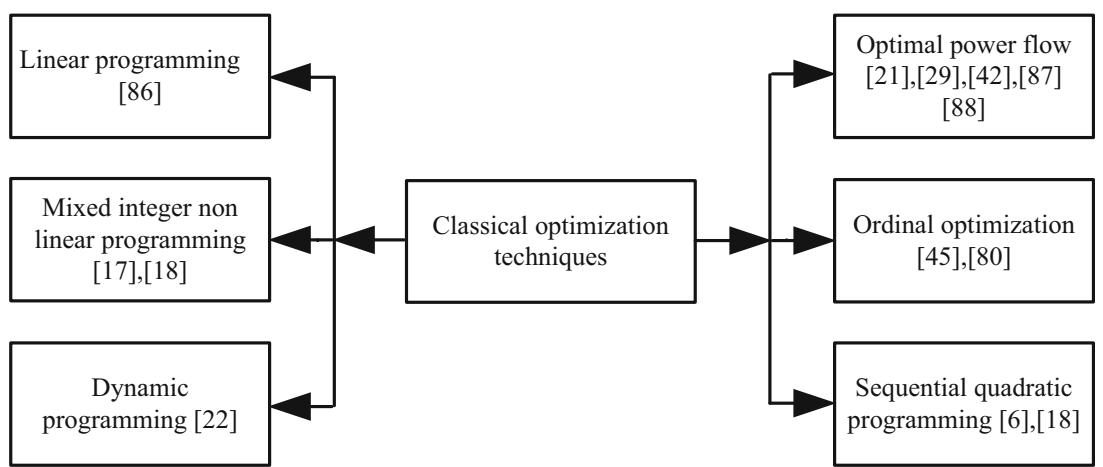

like reliability, power loss, harmonics, voltage fluctuation, stability and power quality [4]. The DG can successfully mitigate these problems; still the DG integration has some technical issues. These issues are discussed as follows.

\section{Power Handling Issue}

Addition of the DG at the distribution level can significantly affect the amount of the power to be handled by types of equipments such as cables, lines, transformer and many other [93]. In [93], it is discussed that the transformer is the mainly affected during power generation increases with power utilization. The system's peak hours are more critical as both base and peak distributed generators will operate to cash in the price premium.

\section{Power Quality Issue}

This issue depends on the technique, which are used for the DG and their modes of the operation. The key cause of harmonics is frequent on/off or frequent change in voltage and current, which adds non-linearity. In addition, too much use of power electronics devices and modern automatically controlled devices produce power quality issues. Though, these devices are very sensitive to voltage-frequency fluctuations [90].

\section{Short Circuit Capacity}

Integration of the DG in existing distribution network increases the short circuit capacity of the system by increasing the steady state current at fault. This depends on size, type and remoteness of the $\mathrm{DG}$ from the
Fig. 4 Artificial intelligent techniques

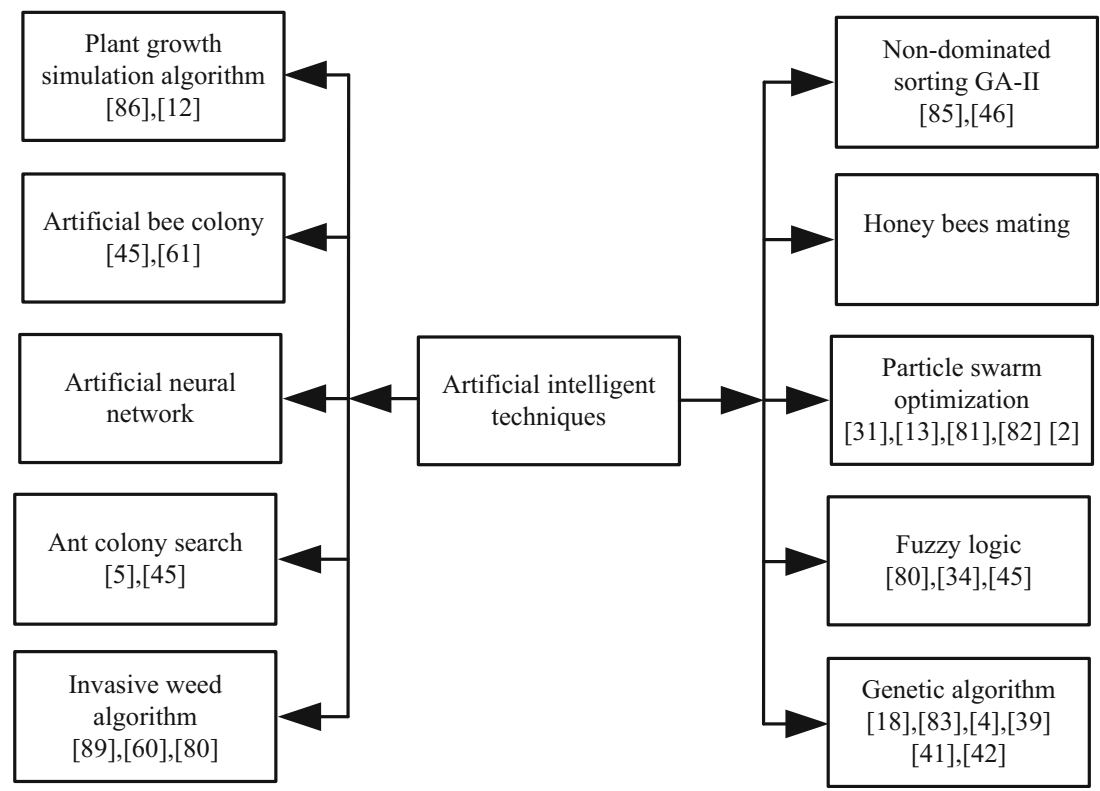


Fig. 5 Miscellaneous techniques

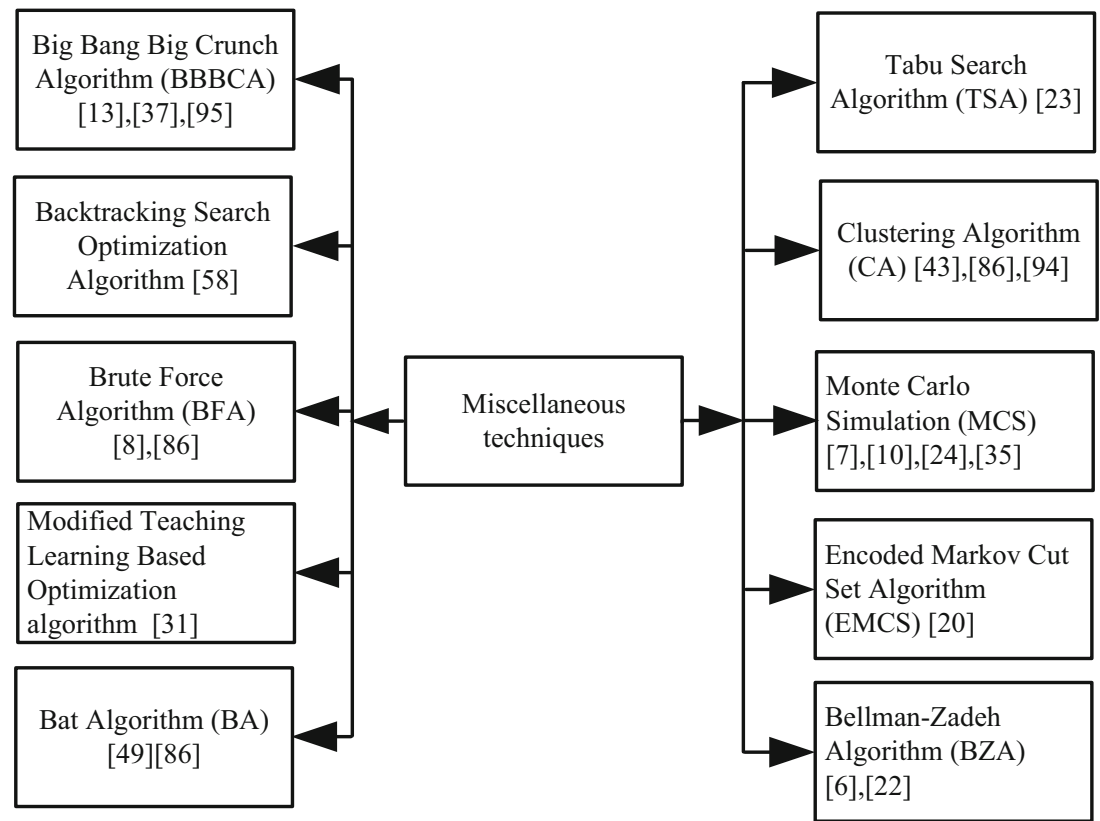

location where fault occurs. This adversely affects the system reliability as well as its safety. Although, sometimes it is desirable to have high short circuit capacity in case of inverter of a line commutated HVDC station, but in general increase in short circuit capacity dominantly indicated problems [90].

\section{Power Conditioning Issues}

The power output pattern of the DG, either AC or DC depends upon the DG technology. The DG source with DC output needs converter to convert DC into AC. In some cases, Cyclo-converters are required to have variable frequency AC supply. The converters may generate harmonics in the system.

\section{Economical Issues}

Cost of the DG is the key factor in its growth and adoption as a new technology [94]. The DG has many advantages; still cost of the DG unit is barrier in its growth. Further, the DG is lagging behind due to regulatory plus policy issues. These issues are point wise discussed here.

\section{Electricity Pricing Issues}

In the present scenario, as price of the electricity is increasing continuously due to increasing demand by all types of the consumers. There is a possibility that distribution companies and industrial load may install their own generation units to partially fulfil their energy demand. This will reduce purchasing of electricity from grid.
Fig. 6 Future promising techniques

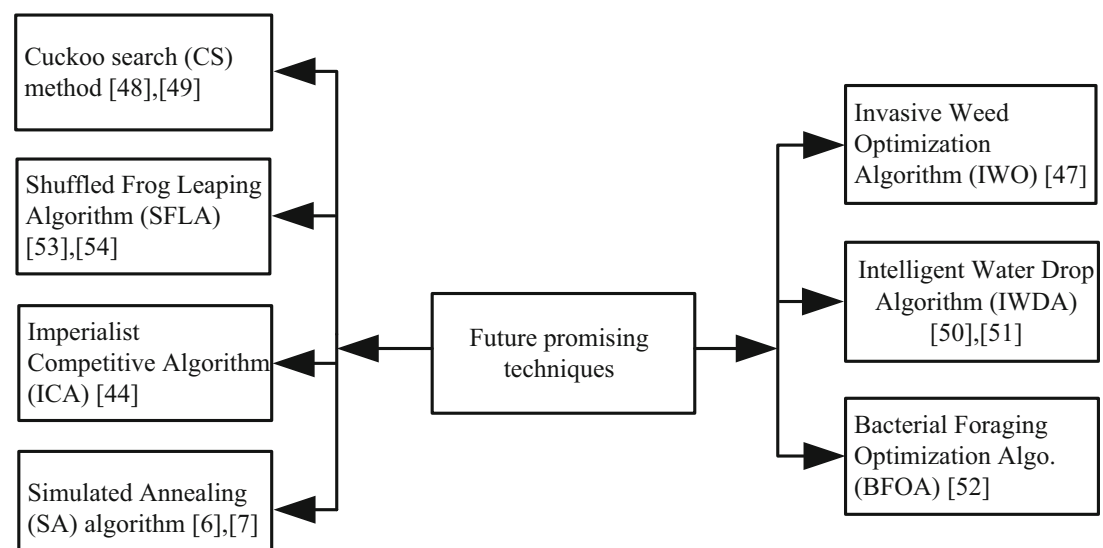




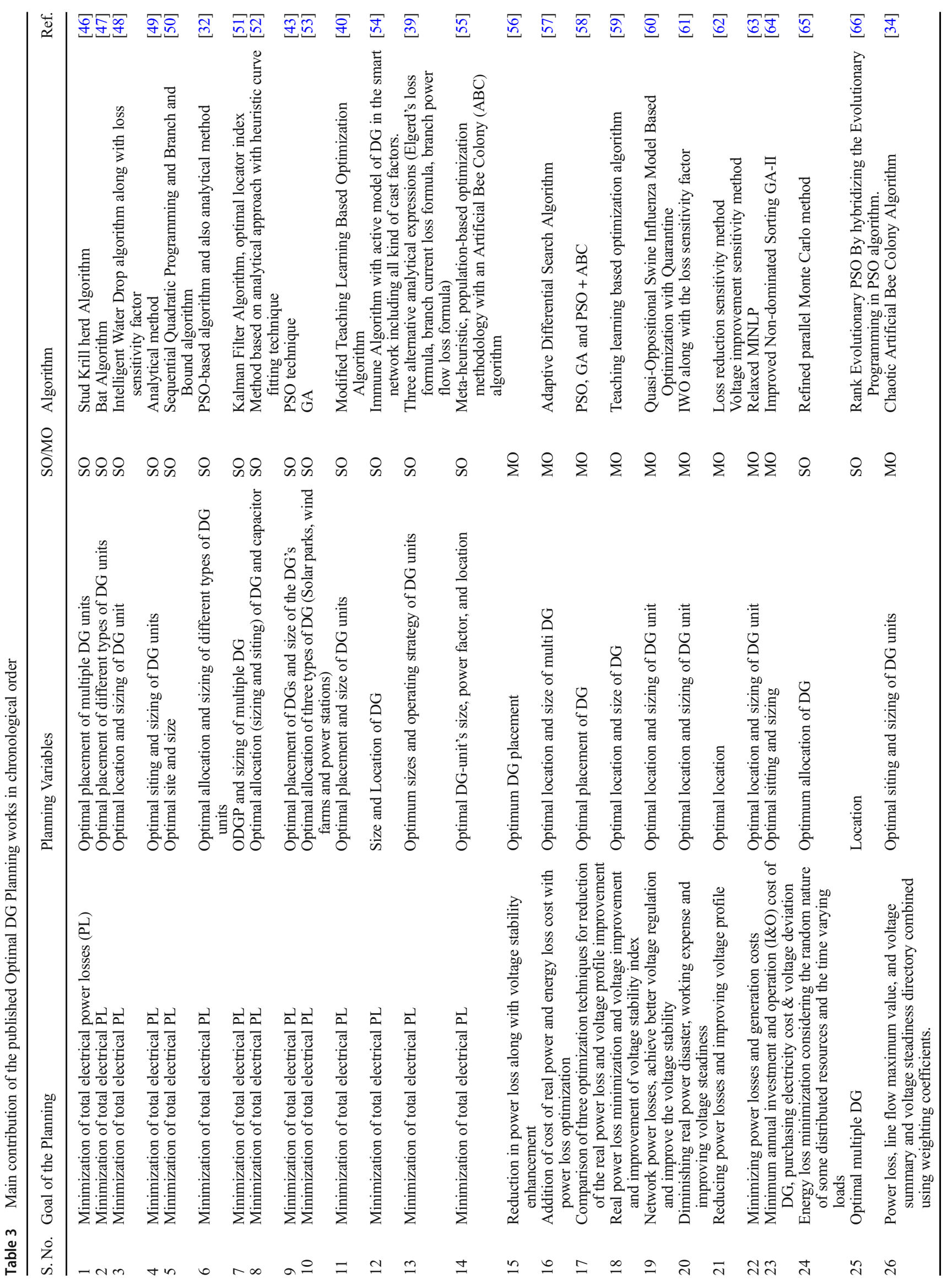




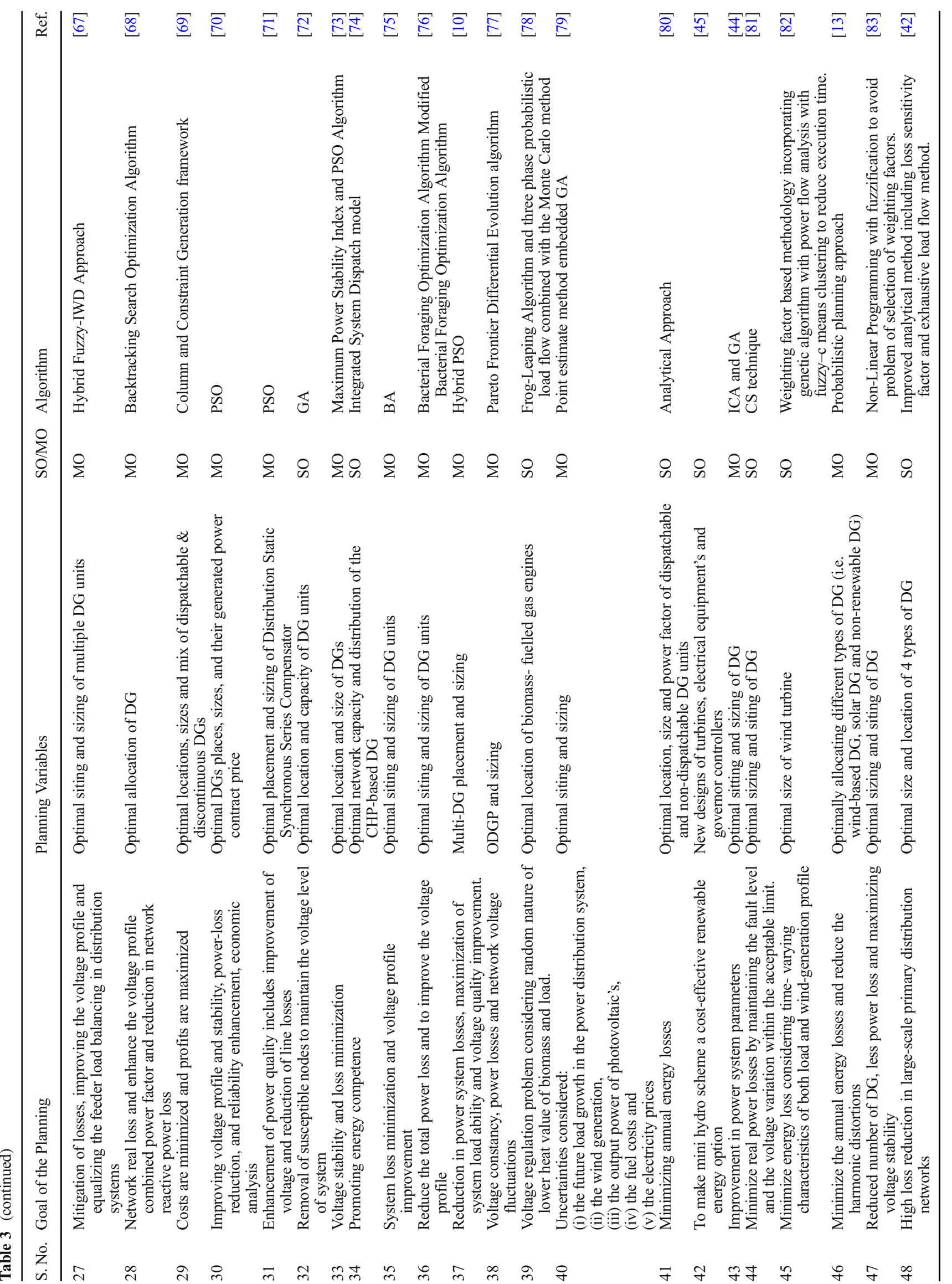




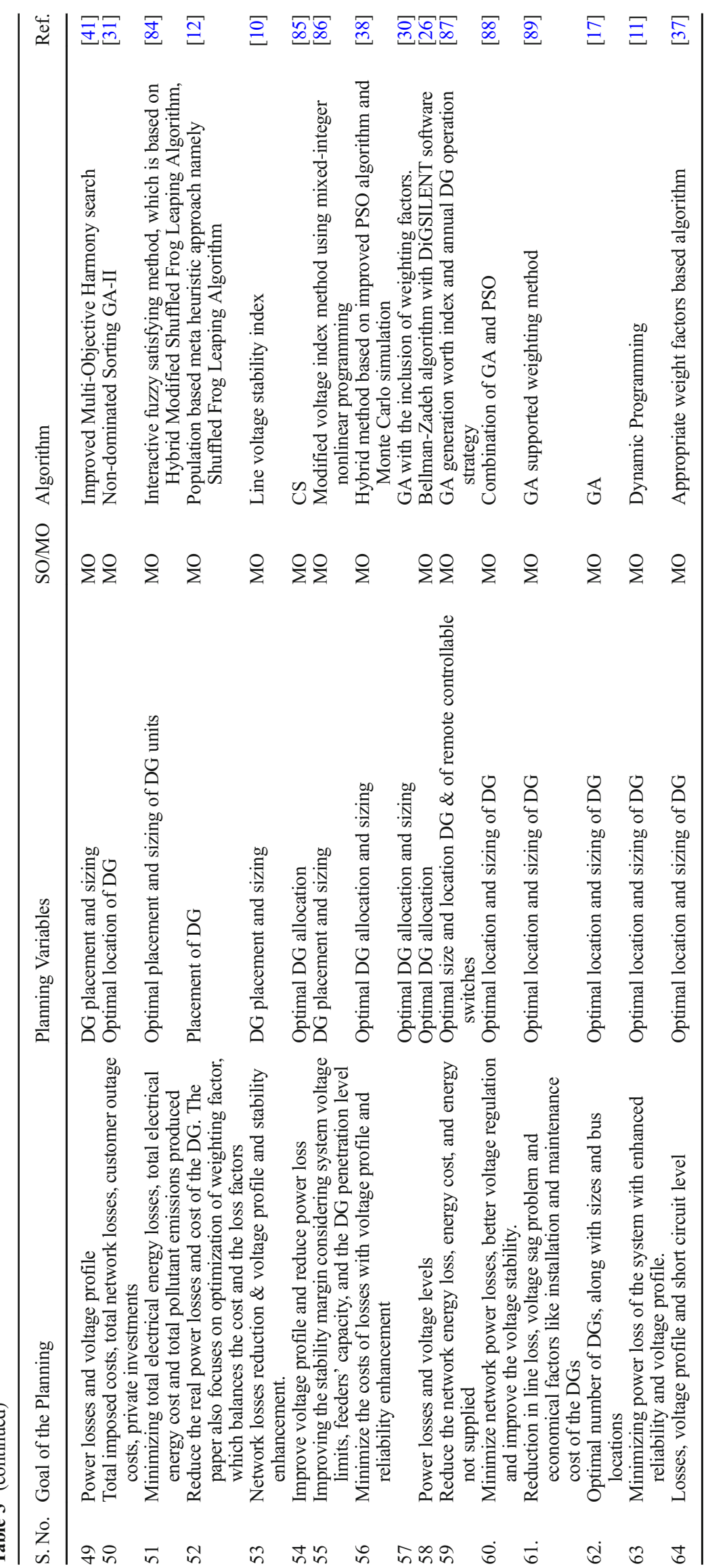


Table 4 Important test systems in literature

\begin{tabular}{llllll}
\hline S. No. & Test System & $\begin{array}{l}\text { Base } \\
\text { power (MVA) }\end{array}$ & $\begin{array}{l}\text { Base } \\
\text { voltage }(\mathrm{kV})\end{array}$ & Figure & Data reference \\
\hline 1 & 12-Bus network & 0.01 & 11 & See Appendix & {$[16,42]$} \\
2 & 16-Bus network & 100 & 23 & {$[99]$} \\
3 & 30-Bus network & & 11 & {$[16,42,100]$} \\
4 & 33-Bus network & & 12.66 & {$[101]$} \\
5 & 41-Bus network & & 33 & {$[16,42,97,102,103]$} \\
6 & 69-Bus network & & 12.66 & {$[104]$} \\
7 & 85-Bus network & & 11 & {$[105]$} \\
8 & 141-Bus network & & 12.47 & \\
9 & IEEE Test System & {$[106]$} & & & \\
\hline
\end{tabular}

Table 5 Important software tools and their brief description (Open source)

S. No. Tool Description

1. The Engineering, Economic, and Environmental Electricity Simulation Tool (E4ST)

2. Panda Power (Load Flow Programme)

3. Electric Grid Test Cases

4. $\quad$ iPST

\section{MATPOWER \\ 6. PSAT (Power System Analysis Toolbox)}

7. Open DSS

8. Smart Residential Load Simulator (SRLS)

9. Grid LAB-D

10. Miscellaneous Data Set
The Engineering, Economic \& Environmental Electricity Simulation Tool (E4ST) was presented in [107].

Radial distribution system has been used to implement this power flow programme, which is based on backward/forward sweep approach. In [108], tutorials to use this software are given. Also, the panda power flow programme may be suitable software for power system analysis [109].

This webpage is intended to provide a repository of publicly available, non-confidential power system test cases [110].

The iPST is open-source software which was designed to provide a stage for examination of security and safety of expanded power system. It is an active power system simulator for simulating the dynamics of the system. It additionally encourages the power grid data-mining utilizing huge-data databases that permit storing time-series of power system related information's [111].

MATPOWER is a software package for solving load flow and system optimization related problems. It was primarily developed as part of the Power Web project [112].

The PSAT is an obliging software for power system examination and modeling. It can assist in power system stability problems with real time analysis, wind turbine models, change of information records from a few configurations. It provides interfaces to GAMS and UWPFLOW programs [113].

The Open DSS is a comprehensive electrical power system simulation tool. It supports nearly all frequency domain (sinusoidal steady-state) analyses, which are commonly performed on electric utility power distribution systems. In addition, it supports many new types of analyses that are designed to meet future needs related to smart grid, grid modernization and renewable energy research. Other features support analysis of such things as energy efficiency in power delivery and harmonic current flow. The Open DSS has room for changes to meet future needs [114].

The SRLS facilitates the study of energy management systems in smart grids. This provides a complete set of user-friendly graphical interfaces to properly model thermostats, air conditioners, furnaces, water heaters, refrigerators, stoves, dish washers, cloth washers, dryers, lights and pool pumps as well as wind, solar, and battery sources of power generation in residential houses. The simulator allows modeling, the way appliances consume power and helps to understand how these contribute to peak demand providing individual and total energy consumption and costs and allowing assessment of generated power by residential power sources. This platform can be a useful tool for researchers and educators to validate and demonstrate models for residential energy management and optimization. It can also be used by residential customers to model and understand energy consumption profiles in households [115].

Grid LAB-D is a power distribution system simulation and analysis tool that provides valuable information to users to design and operate distribution systems. It incorporates the most advanced modelling techniques to deliver the best in end-use modelling. The Grid LAB-D can be integrated with three-phase unbalanced power flow and retail market systems [116].

Several public data sets available from IEEE-PES ISS at [117].

Data related to energy and water [118].

The data related to house hold electric consumption having resolution of 1-min [119].

The data related to house hold electric consumption having resolution of 15-min [120]. 
Table 6 Key features of some popular licensed software

\begin{tabular}{|c|c|c|}
\hline $\begin{array}{l}\text { S. } \\
\text { No. }\end{array}$ & Tool & Description \\
\hline 1. & DIgSILENT & $\begin{array}{l}\text { The Power Factory Monitor (PFM) is multi-functional Dynamic System Monitor, which } \\
\text { can be fully integrated with DIgSILENT Power Factory software. The beauty of PFM } \\
\text { is grid and plant monitoring, fault data record, grid characteristics analysis by offering } \\
\text { easy access to recorded information, analysis trends, verification of system upset } \\
\text { responses and test results [121]. }\end{array}$ \\
\hline 2. & GAMS & $\begin{array}{l}\text { The GAMS is an advanced-level mathematical optimization modeling tool for linear, } \\
\text { nonlinear, and mixed-integer optimization problems. They can be efficiently modeled } \\
\text { and solved using GAMS. The system is tailored for and allows the user to build large } \\
\text { maintainable models that can be adapted to new situations and complex, large-scale } \\
\text { modeling applications. The GAMS develop models in concise pattern and } \\
\text { human-understandable algebraic statements [122]. }\end{array}$ \\
\hline 3. & PSCAD & $\begin{array}{l}\text { PSCAD/EMTDC provides the facility to researchers to build, simulate and model power } \\
\text { system networks with ease and limitless possibilities for simulation. The } \\
\text { PSCAD/EMTDC also incorporates a comprehensive library of system models ranging } \\
\text { from simple passive elements and control functions to electric machines and other } \\
\text { complex devices [123]. }\end{array}$ \\
\hline 4. & ETAP & $\begin{array}{l}\text { ETAP is the wide-ranging electrical engineering software platform for the design, } \\
\text { simulation, operation, and computerization of generation, transmission, distribution, } \\
\text { and industrialized systems. As a fully integrated model-driven enterprise solution, The } \\
\text { ETAP extends its scope from modeling to operation in real-time power management } \\
\text { system [124]. }\end{array}$ \\
\hline
\end{tabular}

Therefore price will get affected as consumers having option to choose power supply either from grid or from own generation unit. This will reduce the market price of electricity and create good competition between different electricity generation companies [8].

\section{Demand Response Effect}

Several countries are having electricity market and for its better financial status, demand response is a major tool. The demand response is less effective in case of the RES due to its intermittent nature [90].

\section{Regulatory Issues}

The DG is more beneficial, if integrated at proper location in distribution system. Still due to lack of transparent policies and regulatory instruments which are associated with DG treatment, this technology is at brimming stage. In order to promote green energy it is necessary to develop new schemes that support integration and implementation of the DG. An appropriate regulatory policy of Government must be developed for future growth of the DGs.

\section{Operation \& Connection Issues}

The DG integration in an existing system may introduce protection and power flow related issues. Further, non-optimal location as well as size also creates many problems, therefore, the optimal location with size should be globally optimized. These issues are point wise discussed below.

\section{Protection system Co-Ordination Issue}

Earlier distribution systems were radial distribution network where power flow was unidirectional, however, after the DG integration, power can flow in both directions and this may cause some critical challenges in existing network.

The DG units can modify fault current level and disturb the settings of protection devices, making it harder to detect fault. Further, it is complicating co-ordination among the protection devices. Presence of the DGs affects speed of reclosing of switch and it may lead to other serious problems. Since, higher reclosing speed may lead to failure of some DG.

The overall protection schemes and their modification depend upon size, type and location of the DG. In order to avoid major modification, the total capacity of the DG should be 5\% [95]. Therefore, a balance is required to manage successful operation of distribution system with RES/non-RES DGs.

\section{Islanding Issues}

Islanding issue comes when power is required to continuously deliver to a part of the system by the DG during 
grid supply is off. It may be challenging for the utility as workers may work on a charged line and it prevents automatic operation of the switching devices. Islanding can be great challenge for synchronization of renewable sources, which results in false tripping at the moment of re-closer operation [8].

\section{Stability}

Traditionally, the distribution systems were passive with radial topology. Moreover, it needs not to be analysed on the basis of stability as system remains stable during most of the circumstances. However, increased penetration of the DG makes necessary to consider system stability including short duration transient and long term steady state stability [90].

\section{Distribution Test Systems and Load Representation}

In present era, looking at the power crisis problem and several other technical and non-technical issues, RES and non-RES DGs are placed near to electrical load centers considering types of loads as: Uniformly distributed, increasingly distributed, centrally distributed, and randomly distributed loads. It is observed in the literature that the majority of the planning of distribution system was carried out for following test systems shown in Table 4.

In [96-98], 12-bus (Indian) System was popularly used in testing of several research works. The 12-bus system data is given in [96-98]. For load flow study, a power base of 0.01 MVA and voltage base of $11 \mathrm{kV}$ can be taken. The one line diagram of 12-bus system is given in Appendix Fig. 7. The 16-bus system was mainly considered in [16, 42]. For study, $100 \mathrm{MVA}$ and voltage base of $23 \mathrm{kV}$ can be suitable base values for power and voltage, respectively. The one line diagram of 16-bus system is presented in Appendix Fig. 8. This system has six capacitors to maintain the system voltage profile at rated value. The 33-bus system data can be obtained from [16, 42, 100]. For load flow study, a power base of 100 MVA and voltage base of $12.66 \mathrm{kV}$ can be considered. The one line diagram of 33-bus system is comprises in Appendix Fig. 9. The 41-bus system data is given in reference [101]. For study, a power base of $100 \mathrm{MVA}$ and voltage base of $33 \mathrm{kV}$ were taken in the literature. The one line diagram of 41-bus system is represented in Appendix Fig. 10. The 69-bus system data is taken from references [16, 42, 97, 102, 103].
For study, a power base of 100 MVA and voltage base of $12.66 \mathrm{kV}$ can be taken. The one line diagram of 69bus system is presented in Appendix Fig. 11. The 85bus system data is given in [104]. For study, a power base of $100 \mathrm{MVA}$ and voltage base of $11 \mathrm{kV}$ can be taken. The one line diagram of 85 -bus system is presented in Appendix Fig. 12. The 141-bus system data is given in [105]. For study, a power base of 100 MVA and voltage base of $12.47 \mathrm{kV}$ can be considered. The one line diagram of 141-bus system is shown in Appendix Fig. 13.

\section{Supportive Tools for Distributed Generation Planning}

Researchers working in the power system have used various research tools to analyse the planning problem for the DG. Therefore, some useful supportive tools, which help greatly in research related to the planning of the DG, have been presented in this section. Tables 5 and 6 can help researchers in working with distribution system including distributed energy sources.

\section{Conclusion}

This paper focuses on optimal planning of DG considering various objective functions and constraints in distribution networks planning. In addition, it also covered the impacts of DG integration on distribution network's voltage, protection scheme, reliability and security. It is evident from literature that DG installation influences technical, environmental as well as economical benefits in distribution network. Thus, this article also discussed the key benefits and shortcomings (technical, environmental and economical) of addition of DGs. Moreover, renewable energy technology with their comparative study is also presented to make this paper more useful. Further, brief overview of several test systems and open source as well as licensed software presented in this article.

This paper also covered application of modern optimization techniques such as Bacterial Foraging Optimization Algorithm, Simulated Annealing Algorithm, Intelligent Water Drop Algorithm, Shuffled Frog Leaping Algorithm and Invasive Weed Optimization Algorithm in optimal siting and sizing of the DG. 


\section{Appendix}

Fig. 7 12-bus system

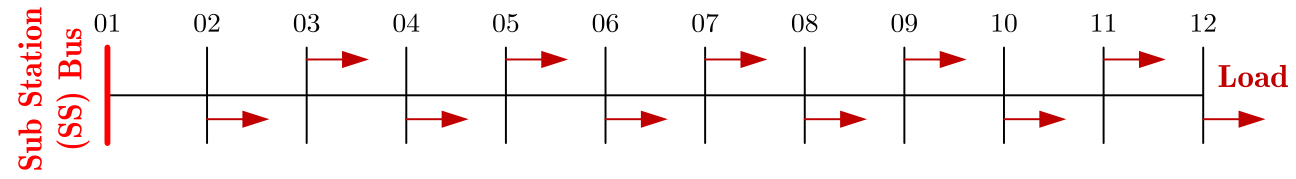

Fig. 8 16-bus RDS (Tie switches are not shown)

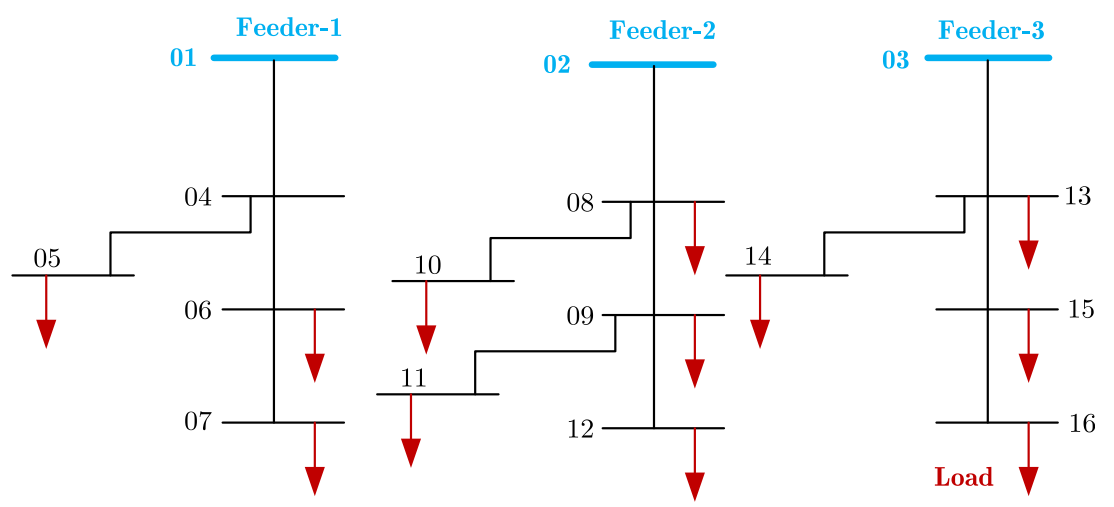

Fig. 9 33-bus RDS

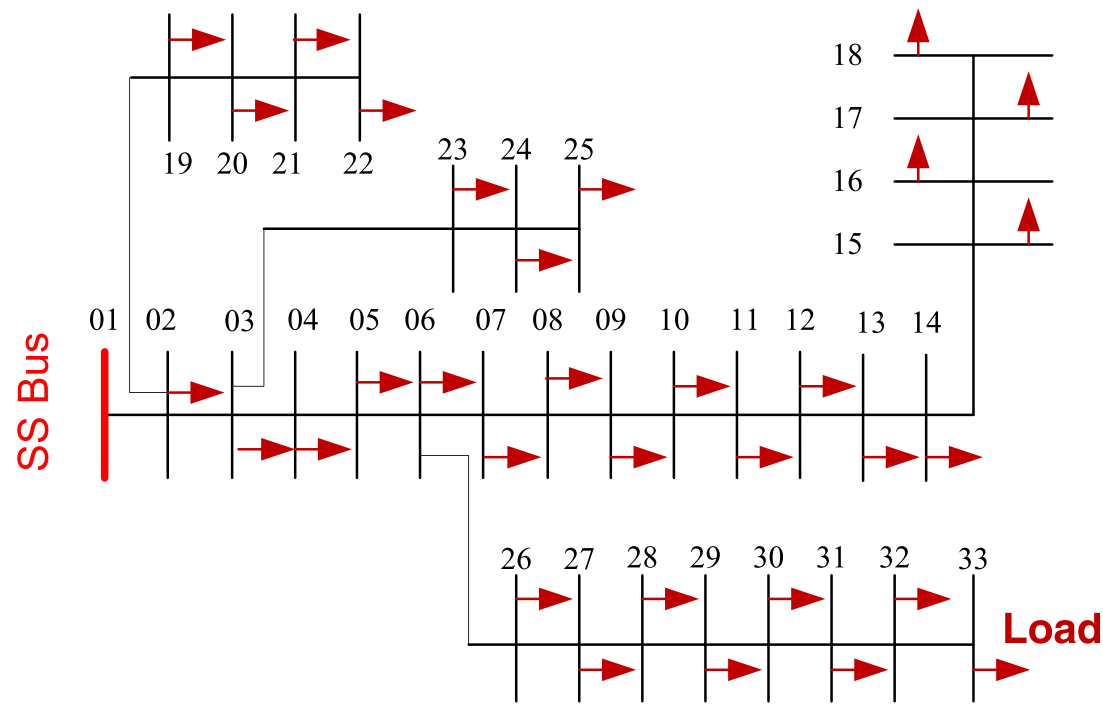


Fig. 10 41-bus RDS

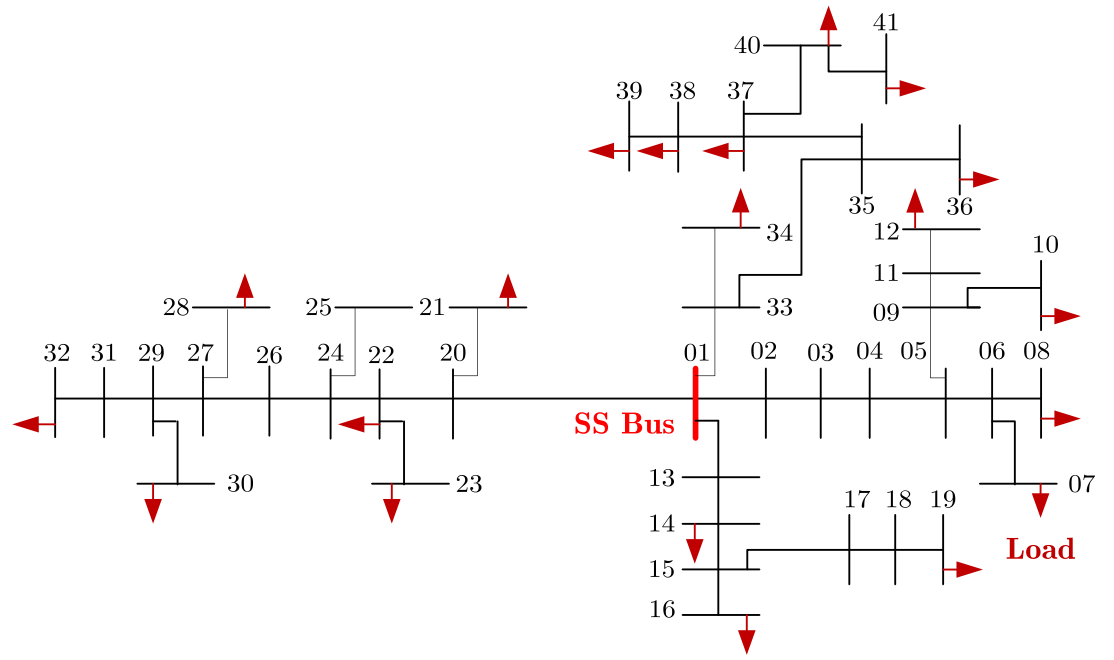

Fig. 11 69-bus RDS

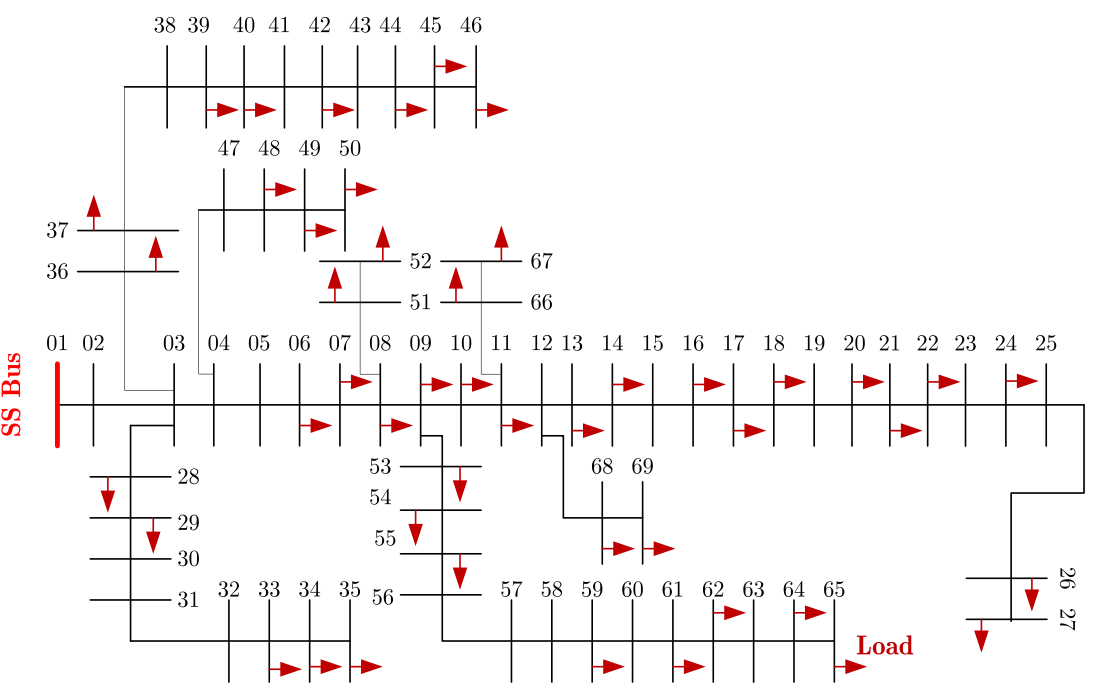


Fig. 12 85-bus RDS

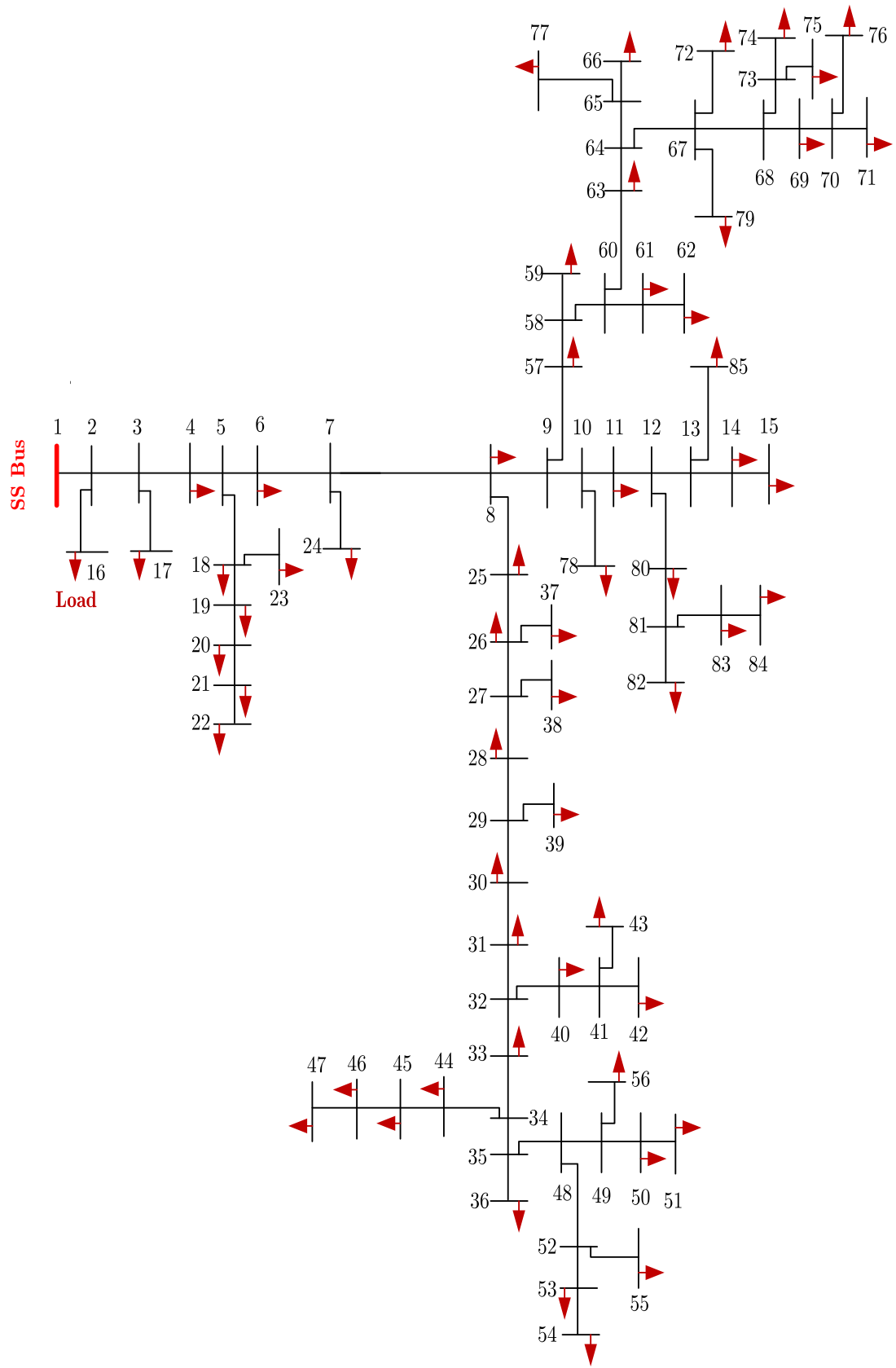


Fig. 13 141-bus RDS

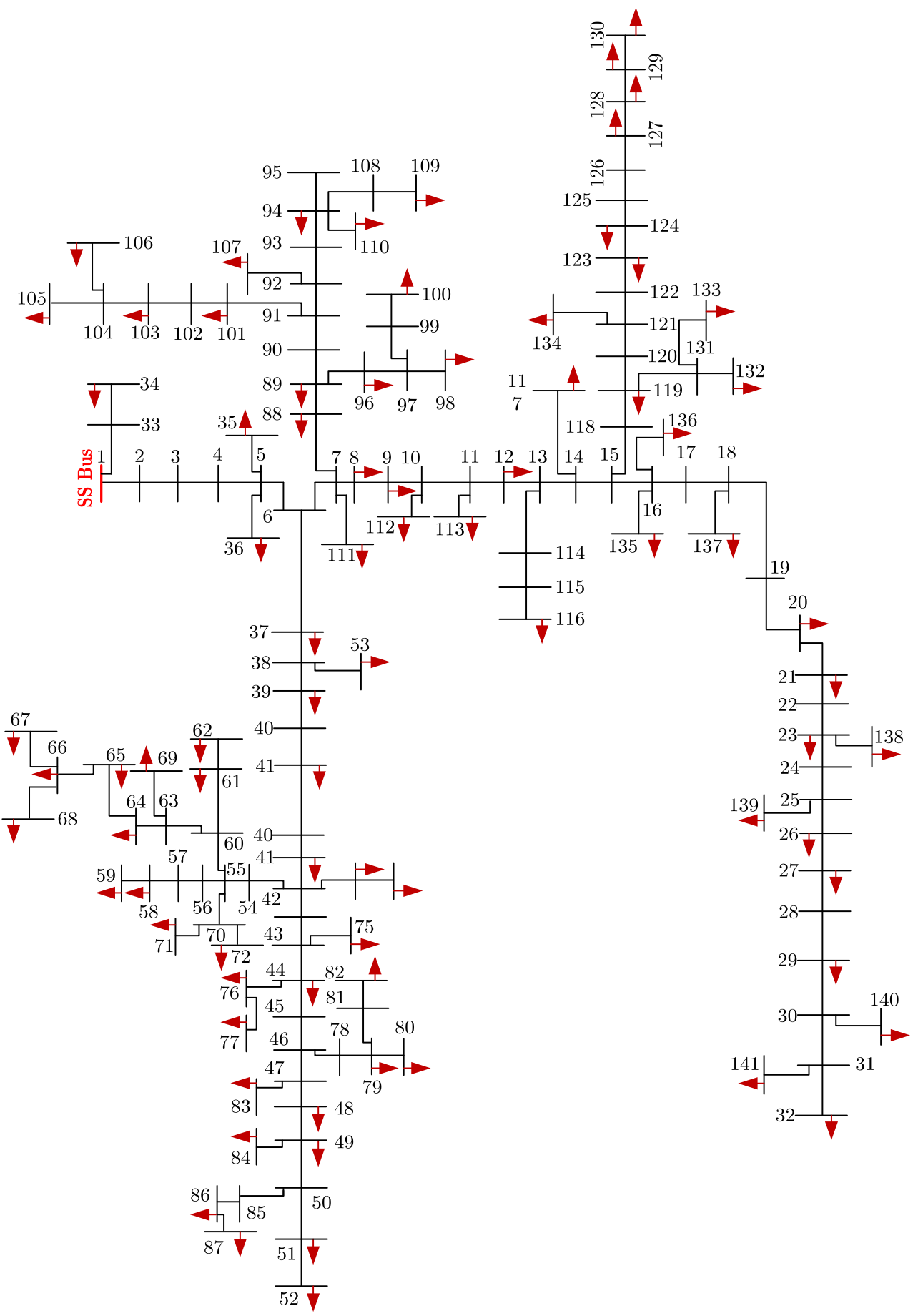


Publisher's Note Springer Nature remains neutral with regard to jurisdictional claims in published maps and institutional affiliations.

\section{References}

1. International Energy Outlook (2013). U.S Energy Information Administration, July 2013

2. Wen-Shan Tan, Mohammad Yusri Hassan, Md Shah Majid, and Hasimah Abdul Rahman, "Optimal distributed renewable generation planning: a review of different approaches," Renew Sust Energ Rev, vol. 18, February 2013, pp. 626-645

3. Angel A.Bayod-Rújula, "Future development of the electricity systems with distributed generation," Energy, vol. 34, no. 3, March 2009, pp. 377-383

4. Prem Prakash and Dheeraj K. Khatod, "Optimal sizing and siting techniques for distributed generation in distribution systems: a review," Renew Sust Energ Rev, vol. 57, May 2016, pp. 111-130,

5. G. Pepermans, J. Driesen, D. Haeseldonckx, R. Belmans, and W. D'haeseleer, "Distributed generation: definition, benefits and issues ," Energy Policy, vol. 33, no. 6, April 2005, pp. 787-798

6. Bindeshwar Singh, V. Mukherjee, and Prabhakar Tiwari, "A survey on impact assessment of DG and FACTS controllers in power systems," Renew Sust Energ Rev, vol. 42, February 2015, pp. 846-882

7. Rajkumar Viral and D.K. Khatod, "Optimal planning of distributed generation systems in distribution system: a review," Renew Sust Energ Rev, vol. 16, no. 7, September 2012, pp. 5146-5165

8. Thomas Ackermann, GöranAndersson, and Lennart Söder, "Distributed generation: a definition," Electr Power Syst Res , vol. 57, no. 3, April 2001, pp. 195-204

9. N. Hadjsaid, J. F. Canard, and F. Dumas, "Dispersed generation impact on distribution networks," IEEE Computer Applications in Power, vol. 12, no. 2, April 1999, pp. 22-28

10. M.M. Aman, G.B. Jasmon, A.H.A. Bakar, and H. Mokhlis, "A new approach for optimum simultaneous multi-DG distributed generation units placement and sizing based on maximization of system loadability using HPSO (hybrid particle swarm optimization) algorithm," Energy, vol. 66, March 2014, pp. 202-215

11. N. Khalesi, N. Rezaei, and M.-R. Haghifam, "DG allocation with application of dynamic programming for loss reduction and reliability improvement," Int J Electr Power Energy Syst, vol. 33, no. 2, February 2011, pp. 288-295

12. Chandrasekhar Yammani, Sydulu Maheswarapu, and Sailajakumari Matam, "Multiobjective optimization for optimal placement and size of DG using shuffled frog leaping algorithm," Energy Procedia, vol. 14, March 2012, pp. 990-995

13. A. A. Abdelsalam and E. F. El, "Probabilistic approach for optimal planning of distributed generators with controlling harmonic distortions," IET Generation, Transmission Distribution, vol. 7, no. 10, October 2013, pp. 1105-1115

14. W El-Khattam and M.M.A Salama, "Distributed generation technologies, definitions and benefits," Electr Power Syst Res, vol. 71, no. 2, October 2004, pp. 119-128

15. J.A. PeÃ §as Lopes, N. Hatziargyriou, J. Mutale, P. Djapic, and N. Jenkins, "Integrating distributed generation into electric power systems: a review of drivers, challenges and opportunities," Electr Power Syst Res, vol. 77, no. 9, July 2007, pp. 1189-1203

16. Hung DQ, Mithulananthan N, Bansal RC (August 2010) Analytical expressions for DG allocation in primary distribution networks. IEEE Transactions on Energy Conversion 25(3):814-820

17. S. Kansal, B. B. R., B. Tyagi, and V. Kumar, "Optimal placement of wind-based generation in distribution networks," in IET conference on renewable Power generation (RPG 2011), September 2011, pp. 1-6
18. "Impact of incresing contribution of dispersed generation on the power system," CIGRE study committee, 2003

19. IEEE, "IEEE, Institute of Electeical and Electronics Engineers," 1547-2003 - IEEE Draft Standard for Interconnecting Distributed Resources with Electric Power Systems

20. EPRI, "The Electrical Power Research Institute,"."About Distributed Reosurses". Full study at: http://www.epri.com/ targetDesc.asp? program $=262184 \&$ value $=03$ T101.0\&objid $=$ 287595. Accessed 27 May 2017

21. Greg Hiemstra van and Alice J. Hovorka, "Fuelwood: the other renewable energy source for Africa?," Biomass Bioenergy, vol. 33, no. 11, November 2009, pp. 1605-1616

22. J. A. P., "Integration of dispersed generation on distribution networks-impact studies," in 2002 IEEE Power Engineering Society Winter Meeting. Conference Proceedings (Cat. No.02CH37309), vol. 1, August 2002, pp. 323-328

23. Maurizio Delfanti, Davide Falabretti, and Marco Merlo, "Dispersed generation impact on distribution network losses," Electr Power Syst Res, vol. 97, April 2013, pp. 10-18

24. Sujatha Kotamarty, Sarika Khushalani, and Noel Schulz, "Impact of distributed generation on distribution contingency analysis," Electr Power Syst Res, vol. 78, no. 9, September 2008, pp. $1537-1545$

25. Chiradeja P, Ramakumar R (November 2004) An approach to quantify the technical benefits of distributed generation. IEEE Transactions on Energy Conversion 19(4):764-773

26. Barin A, Canha L, Abaide A, Machado R (April 2012) Methodology for placement of dispersed generation systems by analyzing its impacts in distribution networks. IEEE Lat Am Trans 10(2):1544-1549

27. D. T. C., L. F. Ochoa, and G. P. Harrison, "DG impact on investment deferral: network planning and security of supply," IEEE Trans Power Syst, vol. 25, no. 2, May 2010, pp. 1134-1141

28. Gianfranco Chicco and Pierluigi Mancarella, "Distributed multigeneration: a comprehensive view," Renew Sust Energ Rev, vol. 13, no. 3, April 2009, pp. 535-551

29. T. Jin, Y. Tian, C. W. Zhang, and D. W. Coit, "Multicriteria planning for distributed wind generation under strategic maintenance," IEEE Transactions on Power Delivery, vol. 28, no. 1, January 2013, pp. 357-367

30. Seyed Amir Hosseini, et al., "Optimal sizing and siting distributed generation resources using a multiobjective algorithm," Turkish Journal of Electrical Engineering \& Computer Sciences, vol. 21, May 2013, pp. 825-850

31. Dehghanian P, Hosseini SH, Moeini-Aghtaie M, Arabali A (October 2013) Optimal siting of DG units in power systems from a probabilistic multi-objective optimization perspective. Int $\mathrm{J}$ Electr Power Energy Syst 51:14-26

32. Peyman Karimyan, G.B. Gharehpetian, M. Abedi, and A. Gavili, "Long term scheduling for optimal allocation and sizing of DG unit considering load variations and DG type," Int J Electr Power Energy Syst, vol. 54, January 2014, pp. 277-287

33. M. A. Kashem, A. D. T. Le, M. Negnevitsky, and G. Ledwich, "Distributed generation for minimization of power losses in distribution systems," in 2006 IEEE Power Engineering Society General Meeting, October 2006

34. N. Mohandas, R. Balamurugan, and L. Lakshminarasimman, "Optimal location and sizing of real power DG units to improve the voltage stability in the distribution system using $\mathrm{ABC}$ algorithm united with chaos," Int J Electr Power Energy Syst, vol. 66, March 2015, pp. 41-52

35. M. Kefayat, A. Lashkar Ara, and S.A. Nabavi Niaki, "A hybrid of ant colony optimization and artificial bee colony algorithm for probabilistic optimal placement and sizing of distributed energy resources ," Energy Convers Manag, vol. 92, March 2015, pp. 149-161 
36. Antonio Colmenar-Santos, Cipriano Reino-Rio, David BorgeDiez, and Eduardo Collado-Fernandez, "Distributed generation: a review of factors that can contribute most to achieve a scenario of DG units embedded in the new distribution networks," Renew Sust Energ Rev, vol. 59, June 2016, pp. 1130-1148

37. Mohab M. Elnashar, Ramadan El Shatshat, and Magdy M.A. Salama, "Optimum siting and sizing of a large distributed generator in a mesh connected system," Electr Power Syst Res, vol. 80, no. 6, June 2010, pp. 690-697

38. Sh. Abdi and K. Afshar, "Application of IPSO-Monte Carlo for optimal distributed generation allocation and sizing," Int J Electr Power Energy Syst, vol. 44, no. 1, January 2013, pp. 786-797

39. Duong Quoc Hung, N. Mithulananthan, and R.C. Bansal, "Analytical strategies for renewable distributed generation integration considering energy loss minimization," Appl Energy, vol. 105, May 2013, pp. 75-85

40. Juan AndrésMartín García and Antonio JoséGil Mena, "Optimal distributed generation location and size using a modified teaching learning based optimization algorithm," Int J Electr Power Energy Syst, vol. 50, September 2013, pp. 65-75

41. K. Nekooei, M. M. Farsangi, H. Nezamabadi-Pour, and K. Y. Lee, "An improved multi-objective harmony search for optimal placement of DGs in distribution systems," IEEE Transactions on Smart Grid, vol. 4, no. 1, March 2013, pp. 557-567

42. D. Q. Hung and N. Mithulananthan, "Multiple distributed generator placement in primary distribution networks for loss reduction," IEEE Trans Ind Electron, vol. 60, no. 4, April 2013, pp. 1700-1708

43. Satish Kansal et al., "Optimal placement of different type of DG sources in distribution networks," Int J Electr Power Energy Syst, vol. 53, December 2013, pp. 752-760

44. Mohammad H. Moradi, Arash Zeinalzadeh, Younes Mohammadi, and Mohammad Abedini, "An efficient hybrid method for solving the optimal sitting and sizing problem of DG and shunt capacitor banks simultaneously based on imperialist competitive algorithm and genetic algorithm," Int J Electr Power Energy Syst, vol. 54, January 2014, pp. 101-111

45. J.A.Laghari, H. Mokhlis, A. H. A. Bakar, Hasmaini Mohammad, "A comprehensive overview of new designs in the hydraulic, electrical equipments and controllers of mini hydro power plants making it cost effective technology," Renew Sust Energ Rev, vol. 20, April 2013, pp. 279-293

46. S.A. ChithraDevi, L. Lakshminarasimman, and R. Balamurugan, "Stud krill herd algorithm for multiple dg placement and sizing in a radial distribution system,"Engineering Science and Technology, an Internation Journal, Vol. 20, Issue 2, April 2017, pp. 748-759

47. S. Remha, S. Chettih, and S. Arif, "Optimal placement of different DG units type in distribution networks based on voltage stability maximization and minimization of power losses," in 2016 8th international conference on modelling, identification and control (ICMIC), November 2016, pp. 867-873

48. Rama Prabha D, Jayabarathi T, Umamageswari R, Saranya S (September 2015) Optimal location and sizing of distributed generation unit using intelligent water drop algorithm. Sustainable Energy Technologies and Assessments 11:106-113

49. Rajkumar Viral and D.K. Khatod, "An analytical approach for sizing and siting of DGs in balanced radial distribution networks for loss minimization," Int J Electr Power Energy Syst, vol. 67, May 2015, pp. 191-201

50. Sandeep Kaur, Ganesh Kumbhar, and Jaydev Sharma, "A MINLP technique for optimal placement of multiple DG units in distribution systems," Int J Electr Power Energy Syst, vol. 63, December 2014, pp. 609-617

51. S. H. Lee and J. W. Park, "Optimal placement and sizing of multiple DGs in a practical distribution system by considering Power loss," IEEE Trans Ind Appl, vol. 49, no. 5, Sep.Oct. 2013 , pp. $2262-2270$
52. S. Gopiya Naik, D.K. Khatod, and M.P. Sharma, "Optimal allocation of combined DG and capacitor for real power loss minimization in distribution networks," Int J Electr Power Energy Syst, vol. 53, December 2013, pp. 967-973

53. Rene Prenc, Davor Škrlec, and Vitomir Komen, "Distributed generation allocation based on average daily load and power production curves," Int J Electr Power Energy Syst, vol. 53, December 2013, pp. 612-622

54. Ma Junjie, Wang Yulong, and Liu Yang, "Size and location of distributed generation in distribution system based on immune algorithm," Systems Engineering Procedia, vol. 4, January 2012, pp. $124-132$

55. F. S. Abu-Mouti and M. E. El-Hawary, "Optimal distributed generation allocation and sizing in distribution systems via artificial bee Colony algorithm," IEEE Transactions on Power Delivery, vol. 26, no. 4, October 2011, pp. 2090-2101

56. U. Sultana, Azhar B. Khairuddin, M.M. Aman, A.S. Mokhtar, and N. Zareen, "A review of optimum DG placement based on minimization of power losses and voltage stability enhancement of distribution system," Renew Sust Energ Rev, vol. 63, September 2016, pp. 363-378

57. Belkacem Mahdad and K. Srairi, "Adaptive differential search algorithm for optimal location of distributed generation in the presence of SVC for power loss reduction in distribution system, " Engineering Science and Technology, an International Journal, vol. 19, no. 3, September 2016, pp. 1266-1282

58. Pushpendra Singh Renu, "Optimum size and location of distributed generation and capacitor for loss reduction using different optimization technique in Power distribution network," International Research Journal of Engineering and Technology (IRJET), vol. 03, March 2016, pp. 709-713

59. Banaja Mohanty and Sasmita Tripathy, "A teaching learning based optimization technique for optimal location and size of DG in distribution network," Journal of Electrical Systems and Information Technology, vol. 3, no. 1, May 2016, pp. 33-44

60. Sharmistha Sharma, Subhadeep Bhattacharjee, and Aniruddha Bhattacharya, "Quasi-oppositional swine influenza model based optimization with quarantine for optimal allocation of DG in radial distribution network," Int J Electr Power Energy Syst, vol. 74, January 2016, pp. 348-373

61. Rama Prabha D, Jayabarathi T (June 2016) Optimal placement and sizing of multiple distributed generating units in distribution networks by invasive weed optimization algorithm. Ain Shams Engineering Journal 7(2):683-694

62. A.K. Singh and S.K. Parida, "Novel sensitivity factors for DG placement based on loss reduction and voltage improvement," Int J Electr Power Energy Syst, vol. 74, January 2016, pp. 453456

63. Antonio JoséGil Mena and Juan AndrésMartín García, "An efficient approach for the siting and sizing problem of distributed generation ," Int J Electr Power Energy Syst, vol. 69, July 2015, pp. $167-172$

64. Ke yan Liu, Wanxing Sheng, Yuan Liu, Xiaoli Meng, and Yongmei Liu, "Optimal sitting and sizing of DGs in distribution system considering time sequence characteristics of loads and DGs," Int J Electr Power Energy Syst, vol. 69, July 2015, pp. 430-440

65. J. A. Martinez and G. Guerra, "A parallel Monte Carlo method for optimum allocation of distributed generation," IEEE Trans Power Syst, vol. 29, no. 6, November 2014, pp. 2926-2933

66. J.J. Jamian, M.W. Mustafa, and H. Mokhlis, "Optimal multiple distributed generation output through rank evolutionary particle swarm optimization ," Neurocomputing, vol. 152, March 2015, pp. $190-198$

67. H. Bagheri Tolabi, M. H. Ali, M. Rizwan, "Novel hybrid fuzzyintelligent water drops approach for optimal feeder multi objective 
reconfiguration by considering multiple-distributed generation," Journal of Operation and Automation in Power Engineering, vol. 2, Autumn 2014, pp. 91-102

68. El-Fergany A (January 2015) Optimal allocation of multi-type distributed generators using backtracking search optimization algorithm. Int J Electr Power Energy Syst 64:1197-1205

69. Wang Z, Chen B, Wang J, Kim J, Begovic MM (September 2014) Robust optimization based optimal DG placement in microgrids. IEEE Transactions on Smart Grid 5(5):2173-2182

70. A. Ameli, S. Bahrami, F. Khazaeli, and M. R. Haghifam, "A multiobjective particle swarm optimization for sizing and placement of DGs from DG Owner's and distribution Company's viewpoints," IEEE Transactions on Power Delivery, vol. 29, no. 4, August 2014, pp. 1831-1840

71. S. Devi and M. Geethanjali, "Optimal location and sizing of distribution static synchronous series compensator using particle swarm optimization," Int J Electr Power Energy Syst, vol. 62, November 2014, pp. 646-653

72. Y. Zhao, Y. An, and Q. Ai, "Research on size and location of distributed generation with vulnerable node identification in the active distribution network," IET Generation, Transmission Distribution, vol. 8, no. 11, November 2014, pp. 1801-1809

73. Ruhaizad Ishak, Azah Mohamed, Ahmed N. Abdalla, and Mohd Zamri Che, "Optimal placement and sizing of distributed generators based on a novel MPSI index," Int J Electr Power Energy Syst, vol. 60, September 2014, pp. 389-398

74. X. Zhang, G. G. Karady, and S. T. Ariaratnam, "Optimal allocation of CHP-based distributed generation on urban energy distribution networks," IEEE Transactions on Sustainable Energy, vol. 5, no. 1, January 2014, pp. 246-253

75. C. Yammani, S. Maheswarapu, and S. K. Matam, "Optimal placement and sizing of DER's with load models using BAT algorithm," in 2013 international conference on circuits, Power and computing technologies (ICCPCT), June 2013, pp. 394-399

76. S. Devi and M. Geethanjali, "Application of modified bacterial foraging optimization algorithm for optimal placement and sizing of distributed generation," Expert Syst Appl, vol. 41, no. 6, May 2014, pp. 2772-2781

77. Mohammad H. Moradi, S.M. Reza Tousi, and Mohammad Abedini, "Multi-objective PFDE algorithm for solving the optimal siting and sizing problem of multiple DG sources," Int J Electr Power Energy Syst, vol. 56, March 2014, pp. 117-126

78. M. Gomez-Gonzalez, F.J. Ruiz-Rodriguez, and F. Jurado, "Probabilistic optimal allocation of biomass fueled gas engine in unbalanced radial systems with metaheuristic techniques," Electr Power Syst Res, vol. 108, March 2014, pp. 35-42

79. V. A. Evangelopoulos and P. S. Georgilakis, "Optimal distributed generation placement under uncertainties based on point estimate method embedded genetic algorithm," IET Generation, Transmission Distribution, vol. 8, no. 3, March 2014, pp. 389-400

80. Duong Quoc Hung, N. Mithulananthan, and Kwang Y. Lee, "Optimal placement of dispatchable and nondispatchable renewable DG units in distribution networks for minimizing energy loss," Int J Electr Power Energy Syst, vol. 55, February 2014, pp. 179-186

81. W. Buaklee and K. Hongesombut, "Optimal DG allocation in a smart distribution grid using cuckoo search algorithm," in 2013 10th International Conference on Electrical Engineering/ Electronics, Computer, Telecommunications and Information Technology, July 2013, pp. 1-6

82. FarukUgranlı and Engin Karatepe, "Optimal wind turbine sizing to minimize energy loss," Int J Electr Power Energy Syst, vol. 53, December 2013, pp. 656-663

83. M. Esmaili, "Placement of minimum distributed generation units observing power losses and voltage stability with network constraints," IET Generation, Transmission Distribution, vol. 7, no. 8, July 2013, pp. 813-821
84. Hasan Doagou-Mojarrad, G.B. Gharehpetian, H. Rastegar, and Javad Olamaei, "Optimal placement and sizing of DG (distributed generation) units in distribution networks by novel hybrid evolutionary algorithm," Energy, vol. 54, June 2013, pp. 129-138

85. Zahra Moravej and Amir Akhlaghi, "A novel approach based on cuckoo search for DG allocation in distribution network," Int J Electr Power Energy Syst, vol. 44, no. 1, January 2013, pp. 672-679

86. R. S. Al, E. F. El-Saadany, and Y. M. Atwa, "Optimal placement and sizing method to improve the voltage stability margin in a distribution system using distributed generation," IEEE Trans Power Syst, vol. 28, no. 1, Feb. 2013, pp. 326-334

87. Mahdi Raoofat and Ahmad Reza Malekpour, "Optimal allocation of distributed generations and remote controllable switches to improve the network performance considering operation strategy of distributed generations," Electric Power Components and Systems, vol. 39, no. 16, Oct. 2011, pp. 1809-1827

88. M.H. Moradi and M. Abedini, "A combination of genetic algorithm and particle swarm optimization for optimal DG location and sizing in distribution systems," Int J Electr Power Energy Syst, vol. 34, no. 1, January 2012, pp. 66-74

89. Soma Biswas, Swapan Kumar Goswami, and Amitava Chatterjee, "Optimum distributed generation placement with voltage sag effect minimization," Energy Convers Manag, vol. 53, no. 1, January 2012, pp. 163-174

90. Naveen Jain, S.N. Singh, "Distributed Generation in Power Systems: An Overview and Key Issues," Proceedings of IEC, December 2009

91. Dondi P, Bayoumi D, Haederli C, Julian D, Suter M (April 2002) Network integration of distributed power generation. J Power Sources 106(1):1-9

92. Kumawat M, Gupta N, Jain N, Saxena D (Sept. 2015) Optimal distributed generation placement in power distributed networks: a review. In: 2015 international conference on electrical, electronics, signals, communication and optimization (EESCO), pp 1-6

93. F. van Overbeeke, "Active networks: distribution networks facilitating integration of distributed generation," 2nd International Symposium on Distributed Generation. Stockholm: Royal Institute of Technology, 2002

94. Vivek Shrivastava Vikas, "A review on distributed generation definitions and DG impacts on distribution system," Nov. 2013

95. S.N. Liew and G. Strbac, "Maximizing penetration of wind generation in existing distribution networks," ser Generation Transmission and Distribution, IEE Proceedings, vol. 149, Aug. 2002

96. S.F Mekhamer, S.A Soliman, M.A Moustafa, and M.E ElHawary, "Load flow solution of radial distribution feeders: a new contribution," International Journal of Electrical Power and Energy Systems, vol. 24, no. 9, Nov. 2002, pp. 701-707

97. Gözel T, Hocaoglu MH (June 2009) An analytical method for the sizing and siting of distributed generators in radial systems. Electr Power Syst Res 79(6):912-918

98. Das D, Nagi HS, Kothari DP (Jul. 1994) Novel method for solving radial distribution networks. IEE Proc. Gener. Transm. Distrib. 141(4):291-298

99. I. Totonchi, H. Al Akash, A. Al Akash, and A. Faza, "Sensitivity analysis for the IEEE 30 bus system using load-flow studies," in 2013 3rd international conference on electric Power and energy conversion systems, Oct. 2013, pp. 1-6

100. Eminoglu U, Hocaoglu MH (Dec. 2008) Distribution systems forward/backward sweep-based Power flow algorithms: a review and comparison study. Electr Power Compon Syst 37(1):91-110

101. Kumar V, Gupta I, Gupta HO, Agarwal CP (Nov. 2005) Voltage and current sensitivities of radial distribution network: a new approach. IEE Proceedings Generation, Transmission and Distribution 152(6):813-818 
102. Ghosh S, Das D (Nov. 1999) Method for load-flow solution of radial distribution networks. IEE Proc Gener Transm Distrib 146(6):641-648

103. Naresh Acharya, Pukar Mahat, and N. Mithulananthan, "An analytical approach for DG allocation in primary distribution network, " Int J Elect Power Energy Syst, vol. 28, no. 10, Dec. 2006, pp. 669-678,

104. D. Das, D.P. Kothari, and A. Kalam, "Simple and efficient method for load flow solution of radial distribution networks," Int J Electr Power Energy Syst, vol. 17, no. 5, Oct. 1995, pp. 335-346

105. Khodr HM, Olsina FG, de Oliveira-De PM, Yusta JM (July 2008) Maximum savings approach for location and sizing of capacitors in distribution systems. Electr Power Syst Res 78(7):1192-1203

106. (Feb. 1995) Bibliography on load models for power flow and dynamic performance simulation. IEEE Trans Power Syst 10(1): 523-538

107. Biao Mao, Daniel Shawhan and Ray Zimmerman. Compendium of simulation software, E4ST [online]. Available: http://e4st.com/wpcontent/uploads/2016/02/e4st1_0b2.zip. Accessed 27 May 2017

108. Panda Power, Compendium of load flow and power flow MATLAB codes [online]. Available: https://github.com/lthurner/ pandapower/blob/master/tutorials/powerflow.ipynb. Accessed 27 May 2017

109. Panda Power, Compendium of load flow and power flow, tutorials [online]. Available:https://pandapower.readthedocs.io/en/v1.3.0/. Accessed 27 May 2017

110. Ti Xu, Electric grid test cases [online]. Available: https:// electricgrids.engr.tamu.edu/. Accessed 27 May 2017

111. iTesla power system tools (Power system simulation tool) [online]. Available: http://www.itesla-pst.org/

112. Ray D. Zimmerman, Carlos E. Murillo-Sánchez. MATLAB power system simulation package [online]. Available: http://www.pserc. cornell.edu/matpower/. Accessed 27 May 2017

113. Power System Analysis and simulation Tool Box (June, 2006) [online]. Available: http://faradayl.ucd.ie/psat.html. Accessed 27 May 2017

114. Distribution System Simulator, distribution circuit simulator [online]. Available:http://sourceforge.net/projects/electricdss/files/. Accessed 27 May 2017

115. Smart residential load simulator, [online]. Mail- J. Miguel Gonzalez. Available: https://uwaterloo.ca/scholar/sites/ca. scholar/files/ccanizar/files/srls2.zip. Accessed 27 May 2017

116. Pacific Northwest National Laboratory (December 2014), Power distribution system simulation and analysis tool [online]. Available : https://sourceforge.net/projects/gridlab-d/files/. Accessed 27 May 2017

117. Open data sets. Available at: http://sites.ieee.org/pes-iss/data-sets/. Accessed 27 May 2017

118. Energy and water data. Available at: https://dataport.cloud/. Accessed 27 May 2017

119. Regional energy consumption data. Available at:http://neea.org/ resource-center/regional-data resources

120. Hourly electrical power consumption data. Available at: https:// archive.ics.uci.edu/ml/datasets/individual+household+electric+ power+consumption. Accessed 27 May 2017
121. DigSILENT Gmbh, Germany, Power factory monitor, [online]. Available at: http://www.digsilent.de. Accessed 27 May 2017

122. GAMS Development Corporation, algebraic mathematics simulator [online]. Available at: https://www.gams.com/download/. Accessed 27 May 2017

123. Manitoba. HVAC research centre, power system computer added designing tool [online]. Available at: https://hvdc.ca/pscad/. Accessed 27 May 2017

124. Etap (1986), USA, Electrical Power System Analysis \& Operation Software [online]. Available at: https://etap.com/demo-download. Accessed 27 May 2017

125. Mohammad Jafar Hadidian-Moghaddam, Saber Arabi-Nowdeh, Mehdi Bigdeli, and Davood Azizian, "A multi-objective optimal sizing and siting of distributed generation using ant lion optimization technique," Ain Shams Engineering Journal, available online, March 2017

126. Othman MM, El-Khattam W, Hegazy YG, Abdelaziz AY (March 2015) Optimal placement and sizing of distributed generators in unbalanced distribution systems using supervised big bang-big crunch method. IEEE Trans Power Syst 30(2):911-919

127. Mohamed Imran A and Kowsalya M, "Optimal size and siting of multiple distributed generators in distribution system using bacterial foraging optimization," Swarm and Evolutionary Computation, vol. 15, April 2014, pp. 58-65

128. P. S. Georgilakis and N. D. Hatziargyriou, "Optimal distributed generation placement in Power distribution networks: models, methods, and future research," IEEE Trans Power Syst, vol. 28, no. 3, Aug. 2013, pp. 3420-3428

129. Florina Rotaru, Gianfranco Chicco, Gheorghe Grigoras, and Gheorghe Cartina, "Two-stage distributed generation optimal sizing with clustering-based node selection," Int J Electr Power Energy Syst, vol. 40, no. 1, Sept. 2012, pp. 120-129

130. M.M. Aman, G.B. Jasmon, H. Mokhlis, and A.H.A. Bakar, "Optimal placement and sizing of a DG based on a new power stability index and line losses," Int J Electr Power Energy Syst, vol. 43, no. 1, Dec. 2012, pp. 1296-1304

131. Chandrasekhar Yammani, Sydulu Maheswarapu, and Sailajakumari Matam, "Multiobjective optimization for optimal placement and size of DG using shuffled frog leaping algorithm," Energy Procedia, vol. 14, March 2012, pp. 990-995, 2011 2nd International Conference on Advances in Energy Engineering (ICAEE)

132. Taher Niknam, Seyed Iman Taheri, Jamshid Aghaei, Sajad Tabatabaei, and Majid Nayeripour, "A modified honey bee mating optimization algorithm for multiobjective placement of renewable energy resources," Appl Energy, vol. 88, no. 12, Dec. 2011, pp. $4817-4830$

133. M. Amjadi, S. J. Peighambardoust, "Review of the proton exchange membranes for fuel cell applications,"Int J Hydrog Energy, vol. 3 5, Sept. 2010, pp. 9349-9384

134. Adel M. Sharaf and Mustafa E. Şahin, "A flexible PV-powered battery-charging scheme for electric vehicles," IETE Tech Rev, vol. 34, no. 2, April 2016, Pages 133-143

135. Joseph E. Aldy, William A. Pizer, and Keigo Akimoto, "Comparing emissions mitigation efforts across countries," Clim Pol, vol. 17, no. 4, Jan. 2016, Pages 501-515 